\title{
Hubungan Nilai-nilai Pola Pikir dan Perilaku Ramah Lingkungan Siswa Sekolah Dasar Adiwiyata
}

\author{
Yudhistira Kusuma1, Hanson E. Kusuma² \\ ${ }^{1}$ Program Studi Magister Arsitektur, SAPPK, Institut Teknologi Bandung. \\ ${ }^{2}$ Kelompok Keahlian Perancangan Arsitektur, SAPPK, Institut Teknologi Bandung. \\ kusumayudhistira@yahoo.com
}

\begin{abstract}
ABSTRAK
Menurunnya kualitas lingkungan hidup akhir-akhir ini mengharuskan adanya perubahan pola pikir dan perilaku manusia. Perubahan tersebut dapat dicapai melalui edukasi lingkungan di sekolah. Indonesia baru-baru ini menggalakkan program Adiwiyata untuk menjadikan sekolah sebagai wadah pendidikan lingkungan hidup. Studi ini bertujuan untuk mengungkap dimensi-dimensi pola pikir (NEP) dan perilaku (GEB) yang muncul pada siswa di sekolah Adiwiyata, serta menjelaskan hubungan diantara keduanya untuk mengevaluasi sejauh mana konsep Adiwiyata mampu mengintervensi pola pikir dan perilaku siswa. Melalui analisis komponen prinsip dan analisis faktor, ditemukan enam dimensi NEP siswa di Sekolah dasar Adiwiyata, yaitu: "Intervensi Destruktif", "Intervensi Konservatif", "Eksploitasi Alam", "Edukasi Lingkungan", "Lingkungan Berkelanjutan", dan "Wawasan Lingkungan". Selain itu, ditemukan juga empat dimensi GEB siswa di Sekolah Dasar Adiwiyata, yaitu: "Sikap ProLingkungan (Individual)", "Sikap Pro-Lingkungan (Kelompok)", "Pemborosan SDA \& Energi", serta "Efisiensi SDA \& Energi". Selanjutnya, analisis korelasi menunjukkan bahwa pola pikir dan perilaku tersebut cenderung hanya terwujud di lingkungan sekolah.
\end{abstract}

Kata kunci: Adiwiyata, edukasi lingkungan, GEB, NEP, perilaku, sekolah

ABSTRACT

The declining quality of the environment lately requires a change in human's environmental value and behavior. This change can be achieved through environmental education in schools. Indonesia has recently promoted the Adiwiyata school program to encourage environmental education. This study aims to reveal the dimensions of value (NEP) and behavior (GEB) that occur in students at Adiwiyata school and explain the relationship between the two to evaluate the extent to which Adiwiyata's concepts can interfere with students' thought patterns and behavior. Through principal component analysis and factor analysis, six dimensions of student's NEP were found in Adiwiyata Elementary School, respectively: "Destructive Interventions", "Conservative Interventions", "Exploitation of Nature", "Environmental Education", "Sustainable Environments", and "Environmental Insights". Besides, four dimensions of student's GEB were found at Adiwiyata Elementary School, respectively: "Pro-Environmental Attitudes (Individual)", "Pro-Environmental Attitudes (Group)", "Waste of Natural Resources \& Energy", and "Efficiency of Natural Resources \& Energy". Furthermore, correlation analysis shows that these values and behavior tend to only be realized in the school environment.

Keywords: Adiwiyata, behavior, environmental education, GEB, NEP, school 


\section{Pendahuluan}

Integrasi program edukasi lingkungan pada berbagai jenjang pendidikan telah dicetuskan dalam lingkup internasional sejak tahun 1972 di Stockholm. Edukasi lingkungan perlu diterima seluruh masyarakat agar mereka memiliki pola pikir dasar dan kesadaran akan lingkungan hidup, sehingga secara tidak langsung menumbuhkan motivasi untuk memperhatikan dan menjaga lingkungan hidup (De \& De, 2004). Berdasarkan hal tersebut, secara praktis lingkungan sekolah berperan penting dalam mendidik siswanya agar menjadi masyarakat yang berwawasan lingkungan. Lingkungan ini dinilai efektif karena kompleksitas faktor-faktor yang terdapat di dalamnya, baik fisik, sosial, maupun personal. Keseluruhan sistem di dalamnya akan secara bersamaan bergerak dan mengedukasi penggunanya (khususnya siswa) sesuai dengan apa yang diharapkan.

Saat ini, Indonesia tengah mengembangkan edukasi lingkungan di berbagai jenjang pendidikan. Program sekolah Adiwiyata yang digagas oleh Kementerian Lingkungan Hidup (KLH) telah mampu membentuk sekolah-sekolah yang berorientasi ramah lingkungan. Secara umum, konsep edukasi lingkungan yang diusung oleh KLH mencakup empat kriteria, yaitu: kebijakan sekolah, kurikulum, kegiatan partisipatif, serta pengelolaan sarana dan prasarana pendukung ramah lingkungan (Permen LH No. 05 Tahun 2013 Tentang Pedoman Pelaksanaan Program Adiwiyata, 2013). Keempat kriteria tersebut dijadikan bahan pertimbangan pemerintah untuk menilai sejauh mana penerapan prinsip ramah lingkungan sebuah sekolah, sehingga dapat ditetapkan sampai level mana sekolah tersebut sesuai dengan konsep Adiwiyata.

Intervensi lingkungan sangat erat kaitannya dengan respons pengguna. Dalam hal ini, tujuan Adiwiyata bisa dikatakan tercapai apabila penggunanya (siswa) memiliki pola pikir dan perilaku yang sesuai dengan prinsip-prinsip ramah lingkungan. Untuk itu, diperlukan adanya studi untuk melihat sejauh mana siswa di sekolah Adiwiyata mampu memiliki pola pikir dan berperilaku ramah lingkungan. Penelitian ini sekaligus mencoba mengembangkan alat uji NEP dan GEB yang telah disesuaikan dengan konteks lokal dalam memperhitungkan nilai pola pikir dan perilaku siswa. Hasil penelitian ini menjadi penting karena terkait dengan pengembangan lingkungan sekolah Adiwiyata dan dapat dijadikan bahan evaluasi untuk implementasi konsep sekolah Adiwiyata ke depan.

\section{Bahan dan Metode}

\subsection{Sekolah Adiwiyata}

Adiwiyata didefinisikan sebagai tempat yang baik dan ideal untuk memperoleh ilmu pengetahuan, norma, dan etika. Istilah ini merujuk kepada visi pembangunan berkelanjutan dan terciptanya kesejahteraan hidup (Kementerian Lingkungan Hidup, 2013). Program Adiwiyata diaplikasikan ke sekolah-sekolah dengan tujuan mewujudkan warga sekolah yang bertanggung jawab dalam upaya perlindungan dan pengelolaan lingkungan hidup.

Program sekolah Adiwiyata pertama kali digulirkan pada tahun 2006. Kemudian, pada tahun 2013, program ini didukung oleh UNESCO dengan mengintegrasikan program Green School Action. Berdasarkan $M o U$ yang ditandatangani UNESCO dan pemerintah Indonesia pada tahun 2014, dibentuklah Adiwiyata Green School Indonesia (AGSI) yang berfokus pada pembangunan manusia di bidang lingkungan hidup (UNESCO, 2018)

Program Adiwiyata memiliki empat komponen utama yang berlandaskan pada prinsip partisipatif dan berkelanjutan. Keempat komponen tersebut adalah: (1) kebijakan yang berwawasan lingkungan; (2) pelaksanaan kurikulum berbasis lingkungan; (3) kegiatan lingkungan berbasis partisipatif, dan (4) pengelolaan sarana pendukung ramah lingkungan (Kementerian Lingkungan Hidup, 2013). 
Sekolah yang dipilih sebagai sekolah Adiwiyata mendapatkan pembinaan dan penghargaan. Pada ranah pembinaan Adiwiyata, sekolah dikembangkan agar dapat meningkatkan kapasitas kelembagaan dan sumber daya manusia dalam mengelola lingkungan hidup. Dalam jangka panjang, sekolah ini akan menjadi model/percontohan sekolah yang ramah lingkungan. Program pembinaan sekolah disesuaikan dengan kebutuhan masing-masing daerah. Pembinaan ini dapat berupa pengembangan materi dan metode pembelajaran lingkungan hidup, pengembangan sumber daya, pengembangan kemitraan, dan sebagainya (Kementerian Lingkungan Hidup, 2012).

Selain pembinaan, sekolah Adiwiyata juga diberikan penghargaan sebagai bentuk apresiasi atas usaha yang telah dilakukan dalam pengelolaan lingkungan. Penghargaan sekolah Adiwiyata terbagi menjadi empat tingkatan, yaitu: (1) Adiwiyata tingkat kabupaten/kota; (2) Adiwiyata tingkat provinsi; (3) Adiwiyata tingkat Nasional dan (4) Adiwiyata mandiri. (Kementerian Lingkungan Hidup, 2012). Saat ini program Adiwiyata terus dikembangkan di berbagai sekolah di Indonesia. Namun, dalam pelaksanaannya terdapat berbagai kendala seperti dokumentasi terkait kebijakan dan pengembangan kurikulum, serta sistem evaluasi dokumen dan penilaian fisik (Kementerian Lingkungan Hidup, 2012).

Penelitian-penelitian dengan latar sekolah Adiwiyata menunjukkan hasil yang progresif dalam membentuk masyarakat ramah lingkungan. Manurung (2011), menemukan bahwa warga sekolah dasar Adiwiyata menunjukkan perilaku yang ramah lingkungan, seperti mengelola tanaman, mengelola sampah, hingga penghematan air dan listrik. Di dalam studi lain, Gusti, et.al. (2015) menyatakan bahwa wawasan lingkungan tentang pengelolaan limbah yang didapatkan siswa sekolah dasar melalui program Adiwiyata memiliki hubungan yang signifikan dengan pola pikir dan keinginan mengelola limbah sekolah. Hasil tersebut sejalan dengan apa yang terjadi di tingkatan SMA, bahwa program Adiwiyata menjadikan siswa memiliki tingkat partisipasi yang cukup aktif dalam mengelola limbah sekolah (Widiyaningrum, Lisdiana, \& Purwantoyo, 2015). Selain itu, temuan lainnya menyatakan bahwa program Adiwiyata tidak hanya mempengaruhi secara spesifik di dalam aspek ramah lingkungan, tetapi juga dapat mempengaruhi secara signifikan aspek umum kognitif, afektif, dan psikomotorik warga sekolah (Saragih, 2012).

\subsection{New Environmental Paradigm (NEP)}

New Environmental Paradigm (NEP) adalah skala pengukuran yang dapat digunakan peneliti untuk mengukur nilai-nilai dan orientasi pola pikir ramah lingkungan (environmental attitude) (Manoli, Johnson, \& Dunlap, 2010). Skala ini pertama kali dikemukakan oleh Dunlap dan Van-Liere pada tahun 1978, kemudian diperbarui dan dikembangkan pada tahun 2000-an (Kurisu, 2015). Secara garis besar, NEP merupakan instrumen kuesioner berbasis skala Likert yang berisi pernyataan yang merepresentasikan pola pikir tentang lingkungan hidup. Pada awalnya, skala ini memiliki tiga dimensi, yaitu: "balance of nature"; "limits to growth"; dan "man over nature" (Dunlap \& Van-Liere, 1978).

Pada penerapannya, peneliti lain menggunakan skala ini dengan beberapa modifikasi agar sesuai dengan konteks dan tujuan penelitian mereka. Manoli, Johnson, dan Dunlap (2010) mengadaptasi skala NEP ke dalam bentuk yang sesuai dengan anak-anak (NEP for children) dengan menambahkan beberapa poin dan mem-parafrase kalimat pernyataan agar mudah dimengerti. Tucker dan Izadpanahi (2017) kemudian mengadaptasi kembali NEP for children untuk diterapkan pada instrumen dengan konteks bangunan sekolah di Australia dengan nama NEP (Children@School).

Studi yang dilakukan Tucker dan Izadpanahi (2017) pada sekolah dasar di Australia dengan menggunakan skala NEP (Children@School) menemukan tiga dimensi baru, yaitu: human intervention (intervensi manusia); environmentally sustainable design (ESD) at 
school (desain ramah lingkungan sekolah); dan eco-rights (hak asasi ekologis). Di dalam studi lain pada lingkup yang lebih luas (di luar sekolah), Manoli, Johnson, dan Dunlap (2010) menemukan tiga dimensi NEP pada anak-anak di Amerika, yaitu: rights of nature (hak asasi alam); eco-crisis (krisis ekologis); dan human exemptionalism (keteladanan). Selain itu, ditemukan pula tiga dimensi NEP pada anak-anak di Spanyol, yaitu: respect for nature (menghormati alam); eco-responsibility (tanggung jawab ekologis); dan ecodeterioration (deteriorasi alam) (Corraliza, Collado, \& Bethelmy, 2013). Dimensi-dimensi $N E P$ dapat ditemukan berbeda pada berbagai studi karena keragaman latar belakang dan budaya, bahkan dapat dikatakan NEP merupakan sebuah paradigma yang multidimensional (Dunlap, Van-Liere, Mertig, \& Jones, 2000).

\subsection{General Ecological Behavior (GEB)}

General Ecological Behavior (GEB) merupakan skala yang dikembangkan oleh Kaiser pada tahun 1988 untuk mengukur komitmen individu terkait perilaku ramah lingkungan. Skala GEB yang pertama kali dikemukakan memiliki tujuh dimensi yang menyentuh keseluruhan aspek ramah lingkungan secara umum, yaitu: (1) prosocial behavior; (2) ecological garbage removal; (3) water and power conservation; (4) ecologically aware consumer behavior; (5) garbage inhibition; (6) volunteering in nature protection activities, dan (7) ecological automobile use (Kaiser F. G., 1998).

Skala GEB pada perkembangannya kemudian diadaptasi oleh Evans, et al. (2007) ke dalam bentuk yang bisa digunakan untuk mengukur perilaku ramah lingkungan anak-anak dalam konteks kehidupan sehari-hari (GEB for children). Lebih lanjut, Tucker dan Izadpanahi (2017) menggunakan kembali skala tersebut di dalam studinya dengan konteks yang lebih sempit (lingkungan sekolah) dengan nama GEB (Children@School). Skala GEB (Children@School) memiliki dua dimensi, yaitu pro-active eco-behaviors dan resource and energy conservation (Tucker \& Izadpanahi, 2017).

Pada penggunaannya poin-poin pada kedua instrumen (NEP dan GEB) harus disesuaikan dengan konteks penelitian. Penyesuaian instrumen ini dapat dilakukan melalui expert judgement maupun pilot study (Tucker \& Izadpanahi, 2017). Hal tersebut bertujuan untuk mereduksi potensi bias yang dapat terjadi karena penggunaan instrumen psikometrik yang tidak sesuai dengan karakteristik ruang lingkup penelitian.

\subsection{Batasan dan Tujuan Penelitian}

Objek penelitian ini adalah sekolah dasar yang mendapatkan penghargaan Adiwiyata di berbagai tingkat di Bandung. Sekolah dasar dipilih karena merupakan medium awal tempat seorang anak mengenal dan belajar tentang lingkungan hidup dan dapat memberikan pengaruh pada berbagai aspek di dalam kehidupan anak (Ghaziani, 2008). Sehingga diasumsikan proses edukasi lingkungan didapatkan murni dari lingkungan sekolah tersebut. Penelitian ini dikhususkan untuk anak kelas lima atau kelas enam, dengan pertimbangan kematangan nalar dan telah mengalami edukasi lingkungan di sekolah Adiwiyata pada sebagian besar waktu tempuh studinya atau selama lebih dari empat tahun. Meskipun demikian, penelitian tentang pengembangan nilai-nilai lingkungan hidup dapat dilakukan sejak fase early childhood atau tiga sampai tujuh tahun (White \& Stoecklin, 2008). Adapun sekolah yang dijadikan sampel pada studi ini dijelaskan pada Tabel 1. 
Tabel 1. Sampel Sekolah Dasar dalam Penelitian

\begin{tabular}{|c|c|c|c|c|}
\hline No. & Nama Sekolah & $\begin{array}{l}\text { Peringkat } \\
\text { Adiwiyata }\end{array}$ & Tahun & Alamat \\
\hline 1 & SD Lab-percontohan UPI & \multirow[t]{2}{*}{$\begin{array}{c}\text { Tingkat } \\
\text { kabupaten/kota }\end{array}$} & 2017 & $\begin{array}{l}\text { Kel. Isola, Komplek } \\
\text { Universitas Pendidikan } \\
\text { Indonesia, Bandung }\end{array}$ \\
\hline 2 & SDN 001 Merdeka & & 2017 & Kel. Braga, Bandung \\
\hline 3 & SD Bianglala & \multirow{2}{*}{ Tingkat provinsi } & 2018 & Kel. Sukarasa, Bandung \\
\hline 4 & SDN 189 Neglasari & & 2018 & Kel. Sekeloa, Bandung \\
\hline 5 & SD Juara Bandung (RZ) & \multirow{2}{*}{ Tingkat Nasional } & 2015 & Kel. Cipadung, Bandung \\
\hline 6 & SDN 1 Manggahang & & 2014 & $\begin{array}{l}\text { Kel. Manggahang, Kab. } \\
\text { Bandung }\end{array}$ \\
\hline 7 & SD BPI & \multirow{2}{*}{ Mandiri } & 2014 & Kel. Lengkong, Bandung \\
\hline 8 & SDN 196 Sukarasa & & 2018 & Kel. Sukarasa, Bandung \\
\hline
\end{tabular}

(Sumber: Hasil analisis, 2018)

Tujuan penelitian ini adalah untuk melihat sejauh mana edukasi lingkungan di sekolah Adiwiyata terinternalisasi ke dalam pola pikir mereka dan bagaimana mereka berkomitmen untuk menerapkannya ke dalam perilaku sehari-hari. Kedua aspek di atas akan tergambar melalui dimensi-dimensi $N E P$ dan $G E B$ yang akan terwujud oleh siswa di sekolah-sekolah sampel. Setelah itu, hubungan di antara kedua aspek tersebut akan diungkap melalui korelasi.

\subsection{Metode Penelitian}

Penelitian ini menggunakan pendekatan kuantitatif eksplanatori. Untuk mengetahui sejauh mana pola pikir dan perilaku ramah lingkungan anak di sekolah Adiwiyata, digunakan instrumen (skala) yang telah umum ditetapkan untuk mengukur kedua dimensi tersebut, yaitu NEP (Children@school) untuk pola pikir (value) dan GEB (children@school) untuk perilaku. Kedua instrumen ini berbasis skala likert sehingga dapat diberikan dalam bentuk kuesioner. Di Indonesia sendiri, penggunaan instrumen NEP dan $G E B$ untuk mengukur kedua hal ini jarang ditemukan. Untuk itu perlu adanya modifikasi di beberapa aspek agar kontekstual dengan Indonesia.

Untuk memudahkan proses pengumpulan data, instrumen NEP (Children@school) dan GEB (children@school) harus diubah menjadi versi bahasa Indonesia. Dalam hal ini, terdapat beberapa penyesuaian variabel operasional. Selain alih bahasa, beberapa deskripsi atau kalimat penjelas variabel disesuaikan dengan gambaran yang sudah familier untuk anak-anak di Indonesia. Beberapa kalimat diubah untuk memudahkan pemahaman, namun tidak menghilangkan nilai variabel yang akan diperhitungkan. Penyesuaian variabel operasional dari kedua instrumen tersebut dapat dilihat pada Tabel 2. 


\section{Tabel 2. Penyesuaian Variabel Operasional NEPChildren@school dan GEB Children@school}

\begin{tabular}{|c|c|c|c|}
\hline Kriteria & Dimensi & Variabel Operasional & Penyesuaian Variabel Operasional \\
\hline & \multirow{8}{*}{$\begin{array}{l}\text { Human } \\
\text { intervention }\end{array}$} & \multirow{2}{*}{$\begin{array}{l}\text { If things don't change; we } \\
\text { will have a big disaster in } \\
\text { the environment soon. }\end{array}$} & $\begin{array}{l}\text { Jika kita selalu membuang sampah } \\
\text { sembarangan, maka akan terjadi bencana } \\
\text { alam. }\end{array}$ \\
\hline & & & $\begin{array}{l}\text { Jika kita boros listrik, maka bumi akan } \\
\text { semakin rusak. }\end{array}$ \\
\hline & & \multirow{2}{*}{$\begin{array}{l}\text { People will someday know } \\
\text { enough about how nature } \\
\text { works to be able to } \\
\text { control it. }\end{array}$} & $\begin{array}{l}\text { Orang-orang di sekitar saya mencintai } \\
\text { lingkungan. }\end{array}$ \\
\hline & & & $\begin{array}{l}\text { Orang-orang akan mengerti cara } \\
\text { mendinginkan kamar tanpa menggunakan } \\
\text { AC. }\end{array}$ \\
\hline & & $\begin{array}{l}\text { When people mess with } \\
\text { nature it has bad results. }\end{array}$ & Merusak alam sekitar akan berakibat buruk. \\
\hline & & $\begin{array}{l}\text { People are clever enough } \\
\text { to keep from ruining the } \\
\text { earth. }\end{array}$ & $\begin{array}{l}\text { Menebang hutan sembarangan akan } \\
\text { menyebabkan bencana banjir dan tanah } \\
\text { longsor. }\end{array}$ \\
\hline & & \multirow{2}{*}{$\begin{array}{l}\text { People are treating } \\
\text { nature badly. }\end{array}$} & $\begin{array}{l}\text { Orang-orang di sekitar saya membuang } \\
\text { sampah sembarangan. }\end{array}$ \\
\hline & & & $\begin{array}{l}\text { Orang-orang di sekitar saya suka menanam } \\
\text { pohon. }\end{array}$ \\
\hline \multirow{10}{*}{$\begin{array}{l}\text { NEP } \\
\text { (Children } \\
\text { @school) }\end{array}$} & \multirow{7}{*}{ ESD at school } & \multirow{2}{*}{$\begin{array}{l}\text { I would be willing to go to } \\
\text { a school which has a focus } \\
\text { on nature. }\end{array}$} & $\begin{array}{l}\text { Sekolah ini mengajarkan saya untuk merawat } \\
\text { lingkungan sekitar. }\end{array}$ \\
\hline & & & $\begin{array}{l}\text { Saya harus menanam dan merawat tanaman } \\
\text { yang ada di sekolah ini. }\end{array}$ \\
\hline & & $\begin{array}{l}\text { I believe that artificial } \\
\text { light in classrooms should }\end{array}$ & $\begin{array}{l}\text { Seharusnya air hujan bisa dipakai sebagai } \\
\text { sumber air di toilet. }\end{array}$ \\
\hline & & $\begin{array}{l}\text { be generated by solar } \\
\text { panels. }\end{array}$ & $\begin{array}{l}\text { Listrik di sekolah ini seharusnya berasal dari } \\
\text { energi matahari (panel surya). }\end{array}$ \\
\hline & & $\begin{array}{l}\text { I would be willing to grow } \\
\text { food in the school garden. }\end{array}$ & Saya ingin sekali bercocok tanam di sekolah. \\
\hline & & $\begin{array}{l}\text { I feel more connected with } \\
\text { nature when classes are } \\
\text { held in outdoor spaces. }\end{array}$ & $\begin{array}{l}\text { Belajar di luar kelas terasa lebih segar dan } \\
\text { menyenangkan. }\end{array}$ \\
\hline & & $\begin{array}{l}\text { It makes me feel better } \\
\text { when we have natural } \\
\text { daylight rather than } \\
\text { artificial light all day in } \\
\text { classrooms. }\end{array}$ & $\begin{array}{l}\text { Saat belajar di kelas, saya lebih suka } \\
\text { diterangi cahaya matahari daripada cahaya } \\
\text { lampu. }\end{array}$ \\
\hline & & $\begin{array}{l}\text { People must still obey the } \\
\text { laws of nature. }\end{array}$ & $\begin{array}{l}\text { Orang-orang harus mematuhi hukum alam } \\
\text { agar tidak terjadi bencana. }\end{array}$ \\
\hline & Eco-rights & $\begin{array}{l}\text { Nature will survive even } \\
\text { with our bad habits on } \\
\text { earth. }\end{array}$ & $\begin{array}{l}\text { Alam sekitar akan baik-baik saja meskipun } \\
\text { kita merusaknya. }\end{array}$ \\
\hline & & & $\begin{array}{l}\text { Orang-orang seharusnya bisa menjual kayu } \\
\text { dari hutan agar menjadi kaya raya. }\end{array}$ \\
\hline
\end{tabular}




\begin{tabular}{|c|c|c|c|}
\hline Kriteria & Dimensi & Variabel Operasional & Penyesuaian Variabel Operasional \\
\hline & & $\begin{array}{l}\text { People are supposed to } \\
\text { rule over the rest of } \\
\text { nature. }\end{array}$ & $\begin{array}{l}\text { Kita semua harus menghemat sumber daya } \\
\text { alam untuk anak dan cucu kita. }\end{array}$ \\
\hline & & $\begin{array}{l}\text { Plants and animals have } \\
\text { as many rights as people } \\
\text { to live. }\end{array}$ & $\begin{array}{l}\text { Hewan dan tanaman memiliki hak untuk } \\
\text { hidup sama seperti manusia. }\end{array}$ \\
\hline \multirow{11}{*}{$\begin{array}{c}\text { GEB } \\
\text { (Children } \\
\text { @school) }\end{array}$} & \multirow{5}{*}{$\begin{array}{l}\text { Pro-active } \\
\text { eco-behaviors }\end{array}$} & $\begin{array}{l}\text { I participate in recycling } \\
\text { activities at School. }\end{array}$ & $\begin{array}{l}\text { Saya ikut melaksanakan daur ulang sampah } \\
\text { di sekolah. }\end{array}$ \\
\hline & & $\begin{array}{l}\text { I work in the school } \\
\text { garden with teachers. }\end{array}$ & $\begin{array}{l}\text { Saya ikut merawat tanaman di sekolah } \\
\text { bersama Ibu/Bapak guru. }\end{array}$ \\
\hline & & $\begin{array}{l}\text { I look at books about the } \\
\text { environment (nature, } \\
\text { trees, and animals). }\end{array}$ & $\begin{array}{l}\text { Saya suka membaca buku tentang alam, } \\
\text { pepohonan, dan hewan. }\end{array}$ \\
\hline & & \multirow{2}{*}{$\begin{array}{l}\text { I pick up litter left behind } \\
\text { by my friends during } \\
\text { recess and lunch breaks. }\end{array}$} & $\begin{array}{l}\text { Saya membuang sampah yang ditinggalkan } \\
\text { teman saya saat jajan di kantin. }\end{array}$ \\
\hline & & & $\begin{array}{l}\text { Jika saya melihat sampah di kolong meja, } \\
\text { saya membuangnya ke tempat sampah. }\end{array}$ \\
\hline & \multirow{6}{*}{$\begin{array}{l}\text { Resource and } \\
\text { energy } \\
\text { conservation }\end{array}$} & $\begin{array}{l}\text { I don't turn on the } \\
\text { classroom lights because } \\
\text { there is always enough } \\
\text { light in my classroom. }\end{array}$ & $\begin{array}{l}\text { Saat belajar, saya tidak menyalakan lampu di } \\
\text { kelas karena sudah cukup terang. }\end{array}$ \\
\hline & & $\begin{array}{l}\text { I leave the class window } \\
\text { open while the heater is } \\
\text { working. }\end{array}$ & $\begin{array}{l}\text { Ruang kelas saya sejuk dan nyaman tanpa } \\
\text { kipas angin atau AC. }\end{array}$ \\
\hline & & $\begin{array}{l}\text { I forget to turn off the } \\
\text { water after washing my } \\
\text { hands in the school toilets. }\end{array}$ & $\begin{array}{l}\text { Saya lupa menutup keran air setelah cuci } \\
\text { tangan di toilet. }\end{array}$ \\
\hline & & $\begin{array}{l}\text { I bring too much food to } \\
\text { school and I have to } \\
\text { throw away the extra } \\
\text { food. }\end{array}$ & $\begin{array}{l}\text { Saya tidak pernah menyisakan bekal atau } \\
\text { jajan yang saya bawa. }\end{array}$ \\
\hline & & $\begin{array}{l}\text { I turn on the air } \\
\text { conditioner rather than } \\
\text { opening the glass window } \\
\text { when it is warm inside. }\end{array}$ & $\begin{array}{l}\text { Saat cuaca panas, saya lebih suka } \\
\text { menyalakan kipas angin atau AC daripada } \\
\text { membuka jendela. }\end{array}$ \\
\hline & & $\begin{array}{l}\text { I forget to turn the lights } \\
\text { off when I leave a } \\
\text { classroom. }\end{array}$ & $\begin{array}{l}\text { Saya lupa mematikan lampu saat } \\
\text { meninggalkan ruangan. }\end{array}$ \\
\hline
\end{tabular}

(Sumber: Hasil analisis, 2018)

Data yang didapatkan dari lapangan kemudian dianalisis secara kuantitatif menggunakan analisis komponen prinsip, analisis faktor, dan analisis korelasi. Analisis komponen prinsip digunakan untuk menyederhanakan keseluruhan data tanpa mengurangi karakteristik data tersebut secara signifikan (Johnson \& Wichern, 1998). Analisis faktor digunakan untuk menentukan variabel laten (dimensi) yang memiliki kemampuan menjelaskan keseluruhan variabel pada masing-masing kategori (Kusuma, Kusuma, Tampubolon, \& Aryanti, 2019). Setelah itu, masing-masing variabel laten dianalisis lebih lanjut menggunakan analisis korelasi untuk menentukan besar hubungan antar variabel laten tersebut, sekaligus menentukan sejauh mana variabel laten tertentu mempengaruhi variabel laten yang lainnya. 


\section{Hasil dan Diskusi}

Data di dalam penelitian ini diperoleh dari delapan sekolah Adiwiyata yang telah ditentukan sebelumnya. Pada masing-masing sekolah, sampel responden yang diambil adalah siswa kelas lima sampai kelas enam atau yang telah berada pada lingkungan sekolah paling sebentar empat tahun, dengan target minimum 50 responden di setiap sekolah. Terdapat perbedaan jumlah responden di setiap sekolah dikarenakan jumlah rombongan belajar yang berbeda-beda pula. Secara keseluruhan, didapatkan 619 responden dengan jumlah 46\% siswa perempuan dan 54\% siswa laki-laki. Seluruh siswa ini memiliki rentang usia yang berbeda, namun didominasi oleh usia sebelas tahun $(59,9 \%)$, sisanya adalah usia sepuluh tahun $(28,1 \%)$, usia 12 tahun $(11,8 \%)$, dan usia 13 tahun $(0,2 \%)$. Keseluruhan data memiliki tingkat reliabilitas rata-rata cronbach's $\alpha=$ 0,5787 atau masih dalam taraf reliable (Saifuddin, 2001).

Pada kajian sebelumnya, telah ditentukan dua kriteria utama yang dapat menjelaskan nilai-nilai (pola pikir) dan perilaku siswa ramah lingkungan, yaitu New Environmental Paradigm Children@school (NEP Children@school) dan General Ecological Behavior Children@school (GEB Children@school). Pada konteks penelitian ini, kedua kriteria tersebut dimodifikasi dan disesuaikan dengan kondisi lingkungan dan budaya di Indonesia, serta ditujukan khusus untuk sekolah Adiwiyata. Oleh karena itu, dalam penelitian ini kriteria tersebut disesuaikan namanya menjadi New Environmental Paradigm - Adiwiyata (NEP-A) dan General Ecological Behavior - Adiwiyata (GEB-A).

\subsection{New Environmental Paradigm - Adiwiyata (NEP-A)}

Berdasarkan data kuesioner yang telah terkumpul, dilakukan analisis komponen prinsip pada masing-masing kriteria $N E P-A$ dan $G E B-A$. Untuk memudahkan proses tersebut, langkah pertama yang dilakukan peneliti adalah memberikan kode (coding) ke setiap variabel operasional yang digunakan pada penelitian. Hal ini dilakukan dengan cara memberikan frasa atau istilah yang dapat mewakili kalimat pernyataan (variabel operasional) yang terdapat pada kuesioner untuk memudahkan analisis di tahap selanjutnya dan memudahkan interpretasi. Pada penamaan di dalam proses coding, peneliti berdiskusi dengan rekan peneliti lain agar nama yang diberikan menjadi seideal mungkin sehingga tidak terjadi bias dan perbedaan pemahaman oleh orang lain. Secara rinci, coding pada kriteria $N E P-A$ dapat dilihat pada Tabel 3.

Tabel 3. Coding pada Indikator $N E P-A$

\begin{tabular}{cll}
\hline No. & \multicolumn{1}{c}{ Variabel Operasional } & \multicolumn{1}{c}{ Kode } \\
\hline 1 & $\begin{array}{l}\text { Jika kita selalu membuang sampah sembarangan, maka akan } \\
\text { terjadi bencana alam. }\end{array}$ & Penumpukan Sampah \\
\hline 2 & Jika kita boros listrik, maka bumi akan semakin rusak. & Energi Tak Terbarukan \\
\hline 3 & Orang-orang di sekitar saya mencintai lingkungan. & Biofilia \\
\hline 4 & $\begin{array}{l}\text { Orang-orang akan mengerti cara mendinginkan kamar tanpa } \\
\text { menggunakan AC. }\end{array}$ & Wawasan Lingkungan \\
\hline 5 & Merusak alam sekitar akan berakibat buruk. & Degradasi Lingkungan \\
\hline 6 & $\begin{array}{l}\text { Menebang hutan sembarangan akan menyebabkan bencana } \\
\text { banjir dan tanah longsor. }\end{array}$ & Penggundulan Lahan \\
\hline 7 & Orang-orang di sekitar saya membuang sampah sembarangan. & Mengotori Lingkungan \\
\hline 8 & $\begin{array}{l}\text { Orang-orang di sekitar saya suka menanam pohon. } \\
\text { Reboisasi }\end{array}$ \\
\hline 9 & $\begin{array}{l}\text { Sekolah ini mengajarkan saya untuk merawat lingkungan } \\
\text { sekitar. }\end{array}$ & Edukasi Lingkungan \\
\hline
\end{tabular}




\begin{tabular}{|c|c|c|}
\hline No. & Variabel Operasional & Kode \\
\hline 10 & $\begin{array}{l}\text { Saya harus menanam dan merawat tanaman yang ada di } \\
\text { sekolah ini. }\end{array}$ & Orientasi Lingkungan Alami \\
\hline 11 & Seharusnya air hujan bisa dipakai sebagai sumber air di toilet. & Daur Ulang Air \\
\hline 12 & $\begin{array}{l}\text { Seharusnya listrik di sekolah ini berasal dari energi matahari } \\
\text { (panel surya). }\end{array}$ & Energi Terbarukan \\
\hline 13 & Saya ingin sekali bercocok tanam di sekolah. & Penghijauan Sekolah \\
\hline 14 & Belajar di luar kelas terasa lebih segar dan menyenangkan. & Menyatu dengan Alam \\
\hline 15 & $\begin{array}{l}\text { Saat belajar di kelas, saya lebih suka diterangi cahaya matahari } \\
\text { daripada cahaya lampu. }\end{array}$ & Penerangan Alami \\
\hline 16 & $\begin{array}{l}\text { Orang-orang harus mematuhi hukum alam agar tidak terjadi } \\
\text { bencana. }\end{array}$ & Bencana Ekologis \\
\hline 17 & Alam sekitar akan baik-baik saja meskipun kita merusaknya. & Deteriorasi Alam \\
\hline 18 & $\begin{array}{l}\text { Orang-orang seharusnya bebas menebang kayu dari hutan agar } \\
\text { menjadi kaya raya. }\end{array}$ & Penebangan Ilegal \\
\hline 19 & $\begin{array}{l}\text { Kita semua harus menghemat sumber daya alam untuk anak } \\
\text { dan cucu kita. }\end{array}$ & $\begin{array}{l}\text { Hemat Energi (Hemat Sumber } \\
\text { Daya) }\end{array}$ \\
\hline 20 & $\begin{array}{l}\text { Hewan dan tanaman memiliki hak untuk hidup sama seperti } \\
\text { manusia. }\end{array}$ & Hak Asasi Alam \\
\hline
\end{tabular}

(Sumber: Hasil analisis, 2019)

Setelah coding selesai dibuat, analisis komponen prinsip dilakukan dengan menggunakan Kaiser's stopping rule. Aturan tersebut diaplikasikan dengan cara mengekstraksi jumlah komponen prinsip yang memiliki eigenvalue lebih dari 1,00. Hal ini berarti setiap komponen prinsip tersebut memiliki variabilitas melebihi variabel terukur dan dapat merepresentasikan atau mewakili variabel terukur (Kaiser H. F., 1960).

Selanjutnya, dilakukan analisis faktor untuk menentukan variabel laten (dimensi) yang nantinya akan menjelaskan variabel-variabel terukur di dalamnya. Pada tahap ini, komponen prinsip diolah menggunakan varimax rotation. Tujuannya adalah agar antar komponen prinsip tidak saling terkorelasi, dengan cara menjadikan factor loading dari variabel terukur tertentu besar pada dimensi tertentu dan mendekati nol pada dimensi yang lain.

Setelah dilakukan analisis faktor, didapatkan enam dimensi yang dapat mewakili kriteria NEP-A, yaitu dimensi "Intervensi Destruktif", "Intervensi Konservatif", "Eksploitasi Alam”, "Edukasi Lingkungan”, "Lingkungan Berkelanjutan”, dan "Wawasan Lingkungan” (Tabel 4). Dimensi-dimensi baru ini disebut juga variabel laten atau variabel besar yang dapat merepresentasikan variabel-variabel kecil/operasional di dalamnya. Dimensidimensi di atas didapatkan dari himpunan kode yang disusun berdasarkan urutan terbesar hingga terkecil dari harga factor loading pada proses varimax rotation. Himpunan tersebut kemudian diberi nama yang sesuai dan dapat mewakili masing-masing variabel yang ada di dalamnya.

Tabel 4. Tabel Variabel Laten $N E P-A$

\begin{tabular}{lcccccc}
\hline & $\begin{array}{c}\text { Intervensi } \\
\text { Destruktif }\end{array}$ & $\begin{array}{c}\text { Intervensi } \\
\text { Konservatif }\end{array}$ & $\begin{array}{c}\text { Eksploitasi } \\
\text { Alam }\end{array}$ & $\begin{array}{c}\text { Edukasi } \\
\text { Lingkungan }\end{array}$ & $\begin{array}{c}\text { Lingkungan } \\
\text { Berkelanjutan }\end{array}$ & $\begin{array}{c}\text { Wawasan } \\
\text { Lingkungan }\end{array}$ \\
\hline $\begin{array}{l}\text { Degradasi } \\
\text { Lingkungan }\end{array}$ & $\mathbf{0 , 8 3}$ & $-0,07$ & $-0,19$ & 0,00 & $-0,10$ & 0,07 \\
\hline Penggundulan Lahan & $\mathbf{0 , 8 2}$ & $-0,15$ & $-0,13$ & 0,09 & $-0,10$ & 0,08 \\
\hline Penumpukan Sampah & $\mathbf{0 , 8 0}$ & $-0,12$ & $-0,05$ & 0,12 & 0,00 & 0,04 \\
\hline $\begin{array}{l}\text { Energi Tak } \\
\text { Terbarukan }\end{array}$ & $\mathbf{0 , 7 3}$ & $-0,07$ & $-0,05$ & 0,02 & 0,28 & 0,04 \\
\hline Biofilia & $-0,11$ & $\mathbf{0 , 8 1}$ & 0,15 & 0,16 & 0,01 & 0,07 \\
\hline Reboisasi & $-0,15$ & $\mathbf{0 , 7 3}$ & 0,03 & 0,24 & 0,00 & 0,03 \\
\hline
\end{tabular}




\begin{tabular}{lcccccc}
\hline & $\begin{array}{c}\text { Intervensi } \\
\text { Destruktif }\end{array}$ & $\begin{array}{c}\text { Intervensi } \\
\text { Konservatif }\end{array}$ & $\begin{array}{c}\text { Eksploitasi } \\
\text { Alam }\end{array}$ & $\begin{array}{c}\text { Edukasi } \\
\text { Lingkungan }\end{array}$ & $\begin{array}{c}\text { Lingkungan } \\
\text { Berkelanjutan }\end{array}$ & $\begin{array}{c}\text { Wawasan } \\
\text { Lingkungan }\end{array}$ \\
\hline $\begin{array}{l}\text { Mengotori } \\
\text { Lingkungan }\end{array}$ & 0,13 & $\mathbf{- 0 , 7 7}$ & 0,13 & $-0,01$ & 0,04 & 0,11 \\
\hline Deteriorasi Alam & $-0,08$ & 0,04 & $\mathbf{0 , 7 5}$ & 0,02 & 0,02 & 0,07 \\
\hline Penebangan Ilegal & $-0,10$ & 0,12 & $\mathbf{0 , 7 0}$ & $-0,09$ & 0,14 & 0,06 \\
\hline Hak Asasi Alam & 0,14 & 0,10 & $\mathbf{- 0 , 5 5}$ & 0,15 & 0,19 & 0,18 \\
\hline Bencana Ekologis & 0,17 & 0,06 & $-0,42$ & 0,39 & 0,04 & 0,21 \\
\hline Orientasi Lingkungan & 0,00 & 0,05 & $-0,07$ & $\mathbf{0 , 7 8}$ & $-0,09$ & 0,11 \\
\hline Alami & 0,09 & 0,09 & 0,03 & $\mathbf{0 , 7 0}$ & 0,14 & $-0,12$ \\
\hline Penghijauan Sekolah & 0,07 & 0,22 & $-0,14$ & $\mathbf{0 , 5 5}$ & 0,04 & 0,08 \\
\hline Edukasi Lingkungan & 0,08 & 0,00 & 0,04 & $-0,03$ & $\mathbf{0 , 7 8}$ & $-0,09$ \\
\hline Energi Terbarukan & $-0,10$ & $-0,17$ & 0,11 & 0,22 & $\mathbf{0 , 5 8}$ & 0,22 \\
\hline Daur Ulang Air & 0,03 & 0,17 & $-0,41$ & $-0,06$ & $\mathbf{0 , 5 4}$ & 0,11 \\
\hline Hemat Energi & 0,06 & $-0,01$ & $-0,07$ & 0,15 & 0,08 & $\mathbf{0 , 6 2}$ \\
\hline Wawasan Lingkungan & 0,04 & 0,22 & 0,21 & 0,03 & 0,07 & $\mathbf{0 , 6 2}$ \\
\hline Menyatu dengan Alam & 0,08 & $-0,21$ & $-0,18$ & $-0,09$ & $-0,06$ & $\mathbf{0 , 5 5}$ \\
\hline Penerangan Alami & & & & & & \\
\hline (Sumber: Hasil analisis, 2019) & & & & &
\end{tabular}

(Sumber: Hasil analisis, 2019)

Berdasarkan hasil varimax rotation pada Tabel 4, dapat dilihat bahwa dimensi yang paling dominan dan sangat menentukan pola pikir dan pemahaman siswa tentang nilainilai ramah lingkungan adalah "Intervensi Destruktif". Dimensi ini mendetailkan dimensi "Human Intervention" pada kriteria NEPChildren@School yang ditemukan oleh Tucker dan Izadpanahi (2017), di mana pada kriteria NEP-A dimensi "Human Intervention" terpecah menjadi dua, yaitu dimensi "Intervensi Destruktif" dan "Intervensi Konservatif". Dimensi "Intervensi Destruktif" mewakili pola pikir siswa tentang intervensi manusia terhadap alam sekitar yang bersifat destruktif, seperti sengaja merusak lingkungan, melakukan penggundulan lahan, membuang sampah sembarangan, dan tidak memperhatikan penggunaan sumber energi tak terbarukan. Pada konteks ini, siswa paling mudah memahami bahwa untuk menjadi manusia yang ramah lingkungan (pro-environment) adalah dengan tidak mengintervensi alam sekitar dengan hal-hal yang bersifat destruktif.

Pada kenyataannya, intervensi yang dilakukan manusia untuk memenuhi kebutuhannya saat ini telah sampai pada tingkat merusak. Peralihan fungsi lahan-lahan hijau dan bentang alam menjadi perkebunan, hunian, industri, hingga wisata seakan sudah menjadi kewajaran. Akhirnya kerusakan bumi dan berkurangnya sumber daya alam tidak terelakkan. Oleh karena itu, preservasi menjadi tindakan yang pertama kali harus dilakukan. Apabila masyarakat belum mampu memperbaiki lingkungan sekitar, paling tidak jangan merusaknya. Dalam konteks edukasi lingkungan, siswa harus dididik untuk terus menjaga keberlangsungan lingkungan alami dengan tidak mengotorinya atau merusaknya. Kegiatan bersih-bersih lingkungan sekolah seminggu sekali atau jadwal piket di kelas merupakan kebiasaan yang harus tetap dijaga. Nasihat-nasihat sederhana seperti "jangan membuang sampah sembarangan" juga sangat penting untuk terus ditanamkan sejak usia anak-anak.

Selain dimensi "Intervensi Destruktif", dimensi lainnya yang menentukan pemahaman dan pola pikir ramah lingkungan siswa adalah dimensi "Intervensi Konservatif". Siswa harus sejak dini dikenalkan dengan lingkungan alami dan diberikan pemahaman bagaimana lingkungan tersebut bekerja agar di kemudian hari mereka lebih mencintai lingkungan. Setelah kecintaan terhadap lingkungan muncul, siswa dilatih untuk bisa memperbaiki keadaan lingkungan dan menciptakan lingkungan yang lebih baik. 
Pada konteks edukasi lingkungan di sekolah, dimensi ini dapat diaplikasikan dengan cara melibatkan siswa dalam seluruh proses perbaikan lingkungan sekolah. Tujuannya adalah menumbuhkan rasa memiliki (sense of belonging) terhadap lingkungan sekitar. Contoh sederhananya adalah dengan melakukan penghijauan di sekolah atau di lingkungan sekitar tempat tinggal masing-masing. Selain itu, memelihara dan merawat hewan ternak juga merupakan kegiatan yang bisa menanamkan sikap konservatif kepada anak-anak. Alternatif lainnya adalah siswa dapat diberikan tanggung jawab untuk membawa tanaman maupun ternaknya sendiri dari rumah dan merawatnya setiap hari di sekolah.

Dimensi selanjutnya yang menentukan kualitas pola pikir ramah lingkungan siswa adalah dimensi "Eksploitasi Alam". Tidak seperti dimensi "Intervensi Destruktif", dimensi ini cenderung memiliki makna yang lebih luas, merujuk kepada bagaimana menjaga lingkungan alami serta aspek-aspek ekologis lainnya agar tetap seimbang dan berproses sebagaimana mestinya. Sumber daya alam memang tercipta untuk dimanfaatkan manusia, akan tetapi manusia seharusnya memiliki batas dalam mengeksploitasi sumber daya, karena pada hakikatnya alam sendiri merupakan makhluk hidup yang juga memiliki hak seperti manusia. Konsekuensi yang akan terjadi apabila manusia gagal dalam menciptakan keseimbangan adalah berkurangnya kualitas lingkungan sekitar hingga terjadinya berbagai bencana alam.

Kualitas pola pikir dan nilai-nilai ramah lingkungan siswa juga didukung oleh dimensi "Edukasi Lingkungan" di sekolah. Sekolah sebagai lingkungan pendidikan utama bagi anak-anak saat ini wajib memiliki mata pelajaran khusus Pendidikan Lingkungan Hidup (PLH) seperti yang telah dilakukan sekolah-sekolah Adiwiyata, karena dari sanalah teori-teori dan pemahaman tentang mengelola lingkungan hidup secara efektif dapat diinternalisasi ke dalam diri siswa. Meskipun demikian, idealnya edukasi lingkungan tidak hanya dilakukan pada mata pelajaran PLH, namun setiap jenis mata pelajaran yang diterima siswa di sekolah seyogyanya mengandung sisipan nilai-nilai edukasi lingkungan.

Selanjutnya, terdapat dimensi "Lingkungan Berkelanjutan" dan dimensi "Wawasan Lingkungan" yang juga mendukung terbentuknya pola pikir dan nilai-nilai ramah lingkungan pada siswa. Siswa sejak dini sudah dapat diperkenalkan dengan berbagai teknologi mutakhir yang terkait dengan lingkungan berkelanjutan seperti teknologi penghasil energi alternatif, teknologi pengelolaan air, dan teknologi lainnya agar mereka memiliki wawasan lingkungan yang baik di masa yang akan datang. Siswa pada usia ini dapat menerima berbagai stimulus dan memahami berbagai upaya pendidikan dari lingkungannya (Sujiono, 2009). Selain itu, siswa tidak hanya dapat belajar di dalam lingkungan sekolahnya. Untuk menambah wawasan lingkungan pada siswa, siswa juga harus sering dibawa ke luar sekolah melihat secara langsung berbagai proses yang terkait dengan keberlangsungan ekologis. Dari sana siswa diharapkan mampu memahami nilainilai yang terkait dengan lingkungan hidup dengan lebih baik.

Apabila dibandingkan dengan dimensi-dimensi $N E P$ versi terdahulu, dimensi $N E P$ $A$ memiliki jumlah yang lebih banyak. Oleh karena itu, dimensi-dimensi baru ini dapat dilihat sebagai penjabaran dari dimensi-dimensi $N E P$ versi terdahulu dan temuan dimensi $N E P$ yang sesuai untuk konteks Indonesia. Penyetaraan dimensi-dimensi $N E P-A$ dengan dimensi-dimensi NEP terdahulu dapat dilihat pada Tabel 5. 
Tabel 5. Tabel Penyetaraan Dimensi NEP

\begin{tabular}{|c|c|c|c|c|}
\hline $\begin{array}{c}\boldsymbol{N E P} \text { (Dunlap \& } \\
\text { Van-Liere, 1978) }\end{array}$ & $\begin{array}{l}\text { NEP for children } \\
\text { (Manoli, Johnson, } \\
\text { \& Dunlap, 2010) }\end{array}$ & $\begin{array}{l}\text { NEP for children } \\
\text { (Corraliza, } \\
\text { Collado, \& } \\
\text { Bethelmy, 2013) }\end{array}$ & $\begin{array}{c}\text { NEP } \\
\text { (children@school) } \\
\text { (Tucker \& } \\
\text { Izadpanahi, 2017) }\end{array}$ & $N E P-A$ \\
\hline Balance of nature & Rights of nature & Respect for nature & Eco-rights & $\begin{array}{c}\text { Lingkungan } \\
\text { berkelanjutan }\end{array}$ \\
\hline \multirow{2}{*}{ Limits to growth } & \multirow{2}{*}{ Eco-crisis } & \multirow{2}{*}{ Eco-deterioration } & & Eksploitasi alam \\
\hline & & & \multirow{2}{*}{$\begin{array}{c}\text { Human } \\
\text { intervention }\end{array}$} & $\begin{array}{l}\text { Intervensi } \\
\text { destruktif }\end{array}$ \\
\hline \multirow[t]{3}{*}{ Man over nature } & \multirow[t]{3}{*}{$\begin{array}{c}\text { Human } \\
\text { exemptionalism }\end{array}$} & \multirow[t]{3}{*}{ Eco-responsibility } & & $\begin{array}{c}\text { Intervensi } \\
\text { konservatif }\end{array}$ \\
\hline & & & \multirow{2}{*}{ ESD at school } & $\begin{array}{c}\text { Edukasi } \\
\text { lingkungan }\end{array}$ \\
\hline & & & & $\begin{array}{c}\text { Wawasan } \\
\text { lingkungan }\end{array}$ \\
\hline
\end{tabular}

(Sumber: Hasil analisis, 2019)

Dimensi-dimensi $N E P-A$ di atas merupakan nilai-nilai pemikiran yang tertanam pada benak manusia tentang bagaimana cara berinteraksi dan mengelola lingkungan sekitar. Apabila ditelaah lebih lanjut, terdapat pola tertentu yang menjadi inti sari dari pemahaman manusia tentang pengelolaan lingkungan. Kelompok dimensi yang paling menentukan kriteria $N E P-A$, yaitu "Intervensi Destruktif", "Intervensi Konservatif", dan "Eksploitasi Alam" adalah kelompok yang mewakili paradigma pengelolaan lingkungan secara aktif. Sedangkan dimensi-dimensi sisanya, yaitu "Edukasi Lingkungan", "Lingkungan Berkelanjutan", dan "Wawasan Lingkungan", mewakili paradigma pengelolaan lingkungan secara pasif.

Kata "aktif" dalam hal ini berarti melakukan pengelolaan lingkungan hidup secara langsung di lapangan (on-site) dengan skala besar. Implikasi dari hasil pengelolaan lingkungan hidup tersebut terjadi saat itu juga. Misalnya, penebangan hutan secara ilegal mengakibatkan kerusakan lingkungan hutan secara langsung dan menghilangkan kemampuan lahan dalam menyerap air hujan sehingga bencana alam rentan terjadi. Begitu pula dengan aksi reboisasi massal yang berimplikasi langsung pada bertambahnya lahan hijau dan mengurangi polusi udara. Dengan kata lain, $N E P-A$ secara dominan dipengaruhi oleh pola pikir yang bersifat urgen atau mendesak, serta memerlukan tindakan langsung di lapangan.

Pada sisi lain, terdapat pula pengelolaan lingkungan hidup secara pasif yang dapat dilakukan dengan menggalakkan edukasi lingkungan di masyarakat. Pengelolaan "pasif" berarti mempersiapkan segala sesuatu yang dapat menanggulangi atau memperbaiki kualitas lingkungan hidup di masa depan, baik secara moral maupun material. Implikasi yang terjadi pada pola pengelolaan pasif ini tidak terjadi secara langsung, tetapi cenderung bersifat penanaman nilai-nilai dan pengembangan ilmu pengetahuan atau teknologi yang terkait dengan pengelolaan lingkungan hidup. Sehingga hasil yang signifikan baru akan dirasakan di masa depan. Meskipun demikian, pola pikir yang bersifat pasif tetap diperlukan untuk mendukung keberlangsungan pengelolaan lingkungan. 


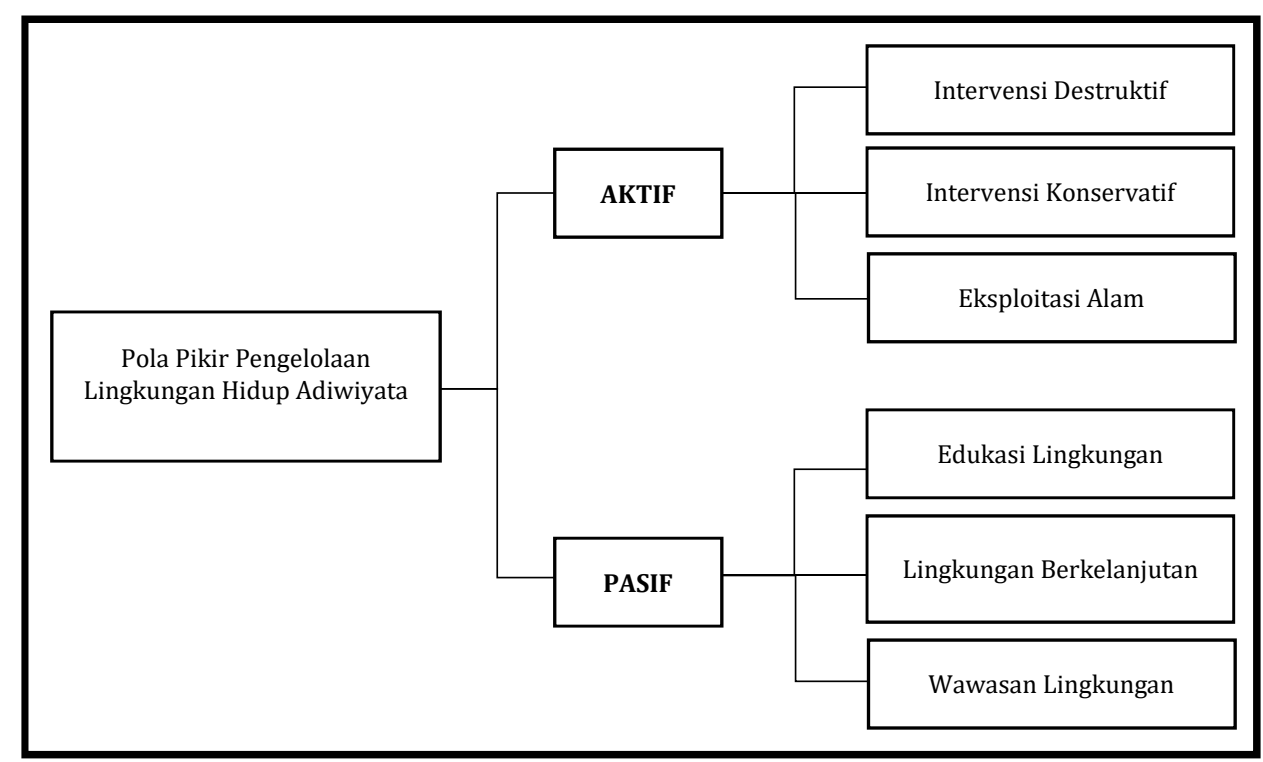

Gambar 1. Diagram Pola Pikir Pengelolaan Lingkungan Hidup Adiwiyata (Sumber: Hasil analisis, 2019)

Menurut Chawla (1999), edukasi lingkungan di sekolah merupakan salah satu sumber yang penting dalam membangun komitmen dalam pengelolaan lingkungan hidup (environmental commitment). Beberapa faktor di lingkungan sekolah yang dapat membangun komitmen tersebut adalah: program-program di sekolah seperti pendidikan lingkungan hidup, ekstrakurikuler, atau fieldtrip; guru yang menginspirasi; serta lingkungan sosial di sekolah seperti aksi pengelolaan hidup di masyarakat (social service). Faktor-faktor tersebut berada di dalam ranah pengelolaan "pasif" yang akan mengembangkan paradigma siswa di sekolah Adiwiyata serta sejalan dengan hal tersebut membangun komitmen untuk menjaga lingkungan hidup di masa depan.

Pada penelitian lainnya oleh Hungerford dan Volk (1990), terdapat empat level dalam keluaran (goal) dari sebuah edukasi lingkungan. Level-level tersebut adalah: (1) Goal Level I, fondasi ekologis; (2) Goal Level II, kesadaran konseptual (isu dan nilai-nilai); (3) Goal Level III, investigasi dan evaluasi; (4) Goal Level IV, aksi (latihan dan aplikasi). Keempat level tersebut adalah tahap-tahap yang harus dilalui oleh individu untuk membangun perilaku ramah lingkungan. Edukasi lingkungan berperan dalam membangun fondasi dan kesadaran konseptual. Dalam hal ini, pengelolaan lingkungan "pasif" menjadi dasar yang penting untuk mengembangkan perilaku ramah lingkungan di kemudian hari.

\subsection{General Ecological Behavior - Adiwiyata (GEB-A)}

Metode yang sama dilakukan pada indikator perilaku ramah lingkungan siswa di sekolah Adiwiyata atau General Ecological Behavior - Adiwiyata (GEB-A). Tahap pertama yang dilakukan adalah memberikan kode (coding) pada setiap variabel operasional pada instrumen $G E B-A$ untuk memudahkan interpretasi selanjutnya. Coding pada kriteria GEB$A$ dapat dilihat pada Tabel 6.

Setelah dilakukan analisis faktor menggunakan varimax rotation, didapatkan empat dimensi yang dapat mewakili kriteria General Ecological Behavior - Adiwiyata (GEB-A). Dimensi tersebut adalah "Sikap Pro-Lingkungan (Individual)", "Sikap Pro-Lingkungan (Kelompok)", "Pemborosan SDA \& Energi”, serta "Efisiensi SDA \& Energi" (Tabel 7). Dimensi-dimensi yang didapat pada penelitian ini menjabarkan lebih detail dua dimensi dari kriteria GEB Children@School milik Tucker dan Izadpanahi (2017). Dimensi "Proactive Eco-behavior" dijabarkan menjadi dua dimensi baru, yaitu "Sikap Pro-Lingkungan (Individual)" dan "Sikap Pro-Lingkungan (Kelompok)". Sementara dimensi "Resource and 
Energy Conservation" dijabarkan menjadi dua dimensi baru "Pemborosan SDA \& Energi" serta "Efisiensi SDA \& Energi".

Tabel 6. Coding pada Kriteria GEB-A

\begin{tabular}{|c|c|c|}
\hline No. & Variabel Operasional & Kode \\
\hline 1 & Saya ikut melaksanakan daur ulang sampah di sekolah. & Aksi Daur Ulang \\
\hline 2 & Saya ikut merawat tanaman di sekolah bersama Ibu/Bapak guru. & $\begin{array}{l}\text { Aksi Pengelolaan } \\
\text { Lingkungan }\end{array}$ \\
\hline 3 & Saya suka membaca buku tentang alam, pepohonan, dan hewan. & Literasi Lingkungan \\
\hline 4 & $\begin{array}{l}\text { Saya membuang sampah yang ditinggalkan teman saya saat jajan } \\
\text { di kantin. }\end{array}$ & $\begin{array}{l}\text { Kampanye } \\
\text { Kebersihan }\end{array}$ \\
\hline 5 & $\begin{array}{l}\text { Jika saya melihat sampah di kolong meja, saya membuangnya ke } \\
\text { tempat sampah. }\end{array}$ & Peduli Lingkungan \\
\hline 6 & $\begin{array}{l}\text { Saat belajar, saya tidak menyalakan lampu di kelas karena sudah } \\
\text { cukup terang. }\end{array}$ & $\begin{array}{l}\text { Pencahayaan Alami } \\
\text { (Mematikan Lampu) }\end{array}$ \\
\hline 7 & Ruang kelas saya sejuk dan nyaman tanpa kipas angin atau AC. & $\begin{array}{l}\text { Penghawaan Alami } \\
\text { (Mematikan AC) }\end{array}$ \\
\hline 8 & Saya lupa menutup keran air setelah cuci tangan di toilet. & Boros Air \\
\hline 9 & Saya tidak pernah menyisakan bekal atau jajan yang saya bawa. & Tidak Mubazir \\
\hline 10 & $\begin{array}{l}\text { Saat cuaca panas, saya lebih suka menyalakan kipas angin atau AC } \\
\text { daripada membuka jendela. }\end{array}$ & $\begin{array}{l}\text { Penghawaan } \\
\text { Artifisial }\end{array}$ \\
\hline 11 & Saya lupa mematikan lampu saat meninggalkan ruangan. & Boros Listrik \\
\hline
\end{tabular}

Tabel 7. Tabel Variabel Laten $G E B-A$

\begin{tabular}{lcccc}
\hline & $\begin{array}{c}\text { Sikap Pro- } \\
\text { Lingkungan } \\
\text { (Individual) }\end{array}$ & $\begin{array}{c}\text { Sikap Pro- } \\
\text { Lingkungan } \\
\text { (Kelompok) }\end{array}$ & $\begin{array}{c}\text { Pemborosan } \\
\text { SDA \& } \\
\text { Energi }\end{array}$ & $\begin{array}{c}\text { Efisiensi } \\
\text { SDA \& } \\
\text { Energi }\end{array}$ \\
\hline Peduli Lingkungan & $\mathbf{0 , 6 7}$ & 0,20 & $-0,06$ & $-0,06$ \\
\hline $\begin{array}{l}\text { Kampanye } \\
\text { Kebersihan }\end{array}$ & $\mathbf{0 , 6 6}$ & 0,03 & 0,13 & $-0,12$ \\
\hline Literasi Lingkungan & $\mathbf{0 , 5 3}$ & 0,39 & $-0,07$ & 0,05 \\
\hline $\begin{array}{l}\text { Pencahayaan Alami } \\
\text { (Mematikan Lampu) }\end{array}$ & 0,49 & $-0,04$ & $-0,06$ & 0,27 \\
\hline Aksi Daur Ulang & 0,10 & $\mathbf{0 , 8 4}$ & 0,12 & 0,03 \\
\hline $\begin{array}{l}\text { Aksi Pengelolaan } \\
\text { Lingkungan }\end{array}$ & 0,12 & $\mathbf{0 , 8 3}$ & $-0,14$ & 0,02 \\
\hline Boros Air & 0,03 & 0,13 & $\mathbf{0 , 7 3}$ & 0,05 \\
\hline Boros Listrik & $-0,16$ & $-0,13$ & $\mathbf{0 , 6 7}$ & 0,15 \\
\hline Penghawaan Artifisial & 0,09 & $-0,06$ & $\mathbf{0 , 6 3}$ & $-0,21$ \\
\hline Tidak Mubazir & $-0,17$ & 0,03 & 0,14 & $\mathbf{0 , 7 8}$ \\
\hline $\begin{array}{l}\text { Penghawaan Alami } \\
\text { (Mematikan AC) }\end{array}$ & 0,40 & 0,06 & $-0,21$ & $\mathbf{0 , 6 0}$ \\
\hline \begin{tabular}{l} 
(Sumber Hasil analis 2019$)$ \\
\hline
\end{tabular} & & & & \\
\hline
\end{tabular}

(Sumber: Hasil analisis, 2019)

Berdasarkan tabel variabel laten pada kriteria $G E B-A$, dapat dilihat bahwa dimensi yang paling menentukan siswa berperilaku ramah lingkungan adalah "Sikap ProLingkungan (Individual)" atau dengan kata lain kesadaran pribadi untuk berperilaku ramah lingkungan. Hal ini meliputi sikap peduli lingkungan yang sudah tertanam dengan baik pada diri siswa. Misalnya, setiap siswa melihat sampah yang berserakan, tanpa diperintah atau diberi imbalan apa pun siswa tersebut akan langsung secara sadar 
memungutnya dan membuangnya ke tempat sampah. Kebiasaan seperti ini merupakan kebiasaan yang sulit apabila tidak dilatih sejak dini, namun setelah terbiasa - kebiasaan seperti ini akan menetap menjadi perilaku yang lazim setiap hari. Perilaku ramah lingkungan ini dapat kita temukan pada masyarakat yang negaranya sudah maju. Biasanya, mereka yang sangat taat pada lingkungan akan resah apabila mengetahui lingkungan sekitarnya mulai tidak bersih atau tidak baik. Oleh karena itu, muncul keinginan untuk mengampanyekan kebersihan dan melakukan perbaikan lingkungan untuk mempengaruhi orang lain agar berbuat hal yang sama, baik secara langsung maupun tidak langsung.

Selanjutnya, dimensi yang menentukan siswa berperilaku ramah lingkungan adalah “Sikap Pro-Lingkungan (Kelompok)". Perbedaan dimensi ini dengan dimensi "Sikap ProLingkungan (Individual)" adalah dimensi ini cenderung dipengaruhi oleh keberadaan kelompok di sekitar siswa dan merupakan sikap ramah lingkungan yang dilakukan secara bersama-sama. Contohnya adalah aksi daur ulang sampah bersama-sama di sekolah, aksi pengelolaan lingkungan di sekitar sekolah yang bekerja sama dengan masyarakat sekitar, atau aksi-aksi bertema lingkungan lainnya yang berasal dari pengaruh sosial di luar sekolah. Siswa akan bergerak apabila ada faktor pemantiknya. Faktor ini bisa berupa program sekolah, regulasi daerah setempat, perlombaan bertema lingkungan, dan sebagainya. Berdasarkan hal ini, dapat dipelajari bahwa pendekatan persuasif juga sangat efektif untuk membuat sekelompok individu memiliki perilaku ramah lingkungan.

Dimensi lainnya yang dapat menentukan seorang siswa berperilaku ramah lingkungan adalah dimensi "Pemborosan SDA \& Energi" dan "Efisiensi SDA \& Energi". Kita dapat melihat bagaimana seorang siswa memperlakukan sumber daya atau energi yang terdapat di sekitarnya, apakah melakukan pemborosan atau justru melakukan efisiensi. Bagi seorang siswa, sikap seperti ini perlu dilatih dan dibimbing terus-menerus karena pemahamannya tentang keberlanjutan lingkungan yang cenderung masih rendah. Sangat mudah bagi mereka untuk membiarkan alat-alat elektronik terus menyala atau menggunakan air bersih untuk bermain-main seenaknya. Oleh karena itu, pengawasan dari orang dewasa sangat penting bagi siswa dalam menempuh fase edukasi lingkungan.

Penyetaraan dimensi juga dilakukan pada kriteria GEB-A dengan GEB versi terdahulu. Perubahan yang signifikan baru ditemukan pada $G E B$ versi Tucker dan Izadpanahi (2017). Dimensi GEB yang berjumlah tujuh variabel direduksi menjadi dua variabel. Sementara dalam temuan penelitian ini, dua buah dimensi $G E B$ tadi dijabarkan kembali menjadi empat dimensi GEB-A (Tabel 8).

Tabel 8. Tabel Penyetaraan Dimensi GEB

\begin{tabular}{|c|c|c|c|}
\hline GEB (Kaiser F. G., 1998) & $\begin{array}{c}\text { GEB for children } \\
\text { (Evans, Brauchle, \& } \\
\text { Shapiro, 2007) }\end{array}$ & $\begin{array}{c}\text { GEB } \\
\text { (children@school) } \\
\text { (Tucker \& } \\
\text { Izadpanahi, 2017) } \\
\end{array}$ & $G E B-A$ \\
\hline Prosocial behavior & \multirow{7}{*}{$\begin{array}{c}\text { (Tidak } \\
\text { menghadirkan } \\
\text { dimensi, hanya } \\
\text { penyesuaian } \\
\text { pada } \\
\text { aplikasi/teknik } \\
\text { pengumpulan } \\
\text { data) }\end{array}$} & \multirow{5}{*}{$\begin{array}{l}\text { Pro-active Eco- } \\
\text { behavior }\end{array}$} & $\begin{array}{l}\text { Sikap Pro-Lingkungan } \\
\text { (Individual) }\end{array}$ \\
\hline Ecological garbage removal & & & \multirow{4}{*}{$\begin{array}{l}\text { Sikap Pro-Lingkungan } \\
\text { (Kelompok) }\end{array}$} \\
\hline $\begin{array}{c}\text { Ecologically aware consumer } \\
\text { behavior }\end{array}$ & & & \\
\hline Garbage inhibition & & & \\
\hline $\begin{array}{l}\text { Volunteering in nature } \\
\text { protection activities }\end{array}$ & & & \\
\hline Ecological automobile use & & \multirow{2}{*}{$\begin{array}{l}\text { Resource and } \\
\text { Energy } \\
\text { Conservation }\end{array}$} & $\begin{array}{c}\text { Pemborosan SDA \& } \\
\text { Energi }\end{array}$ \\
\hline Water and power conservation & & & $\begin{array}{c}\text { Efisiensi SDA \& } \\
\text { Energi }\end{array}$ \\
\hline
\end{tabular}


Apabila dilihat karakteristiknya, keempat dimensi tersebut memiliki dua jenis lingkungan yang mampu mendukung aktifnya kriteria $G E B-A$, yaitu di dalam sekolah dan di luar sekolah. Dimensi yang dominan seperti "Sikap Pro-Lingkungan (Individu)" dan "Sikap Pro-Lingkungan (Kelompok)" cenderung merupakan dimensi GEB-A yang dapat diaktifkan di dalam sekolah (Gambar 2). Hal tersebut disebabkan oleh aturan yang mengikat siswa secara tidak langsung dalam menjalankan kegiatan-kegiatan pengelolaan lingkungan di sekolah. Contohnya seperti membuang sampah pada tempatnya, mengingatkan satu sama lain tentang menjaga lingkungan, maupun kegiatan pengelolaan lingkungan lain yang dikerjakan bersama-sama di dalam lingkungan sekolah. Sementara, kriteria GEB-A lainnya dapat terjadi di luar lingkungan sekolah sebagai bentuk dari penerapan pola perilaku yang telah siswa pelajari di dalam lingkungan sekolah. Oleh karena itu, fungsi pengawasan sebaiknya tetap dilakukan meskipun siswa berada di luar lingkungan sekolah, seperti di rumah atau di tempat-tempat umum lainnya.

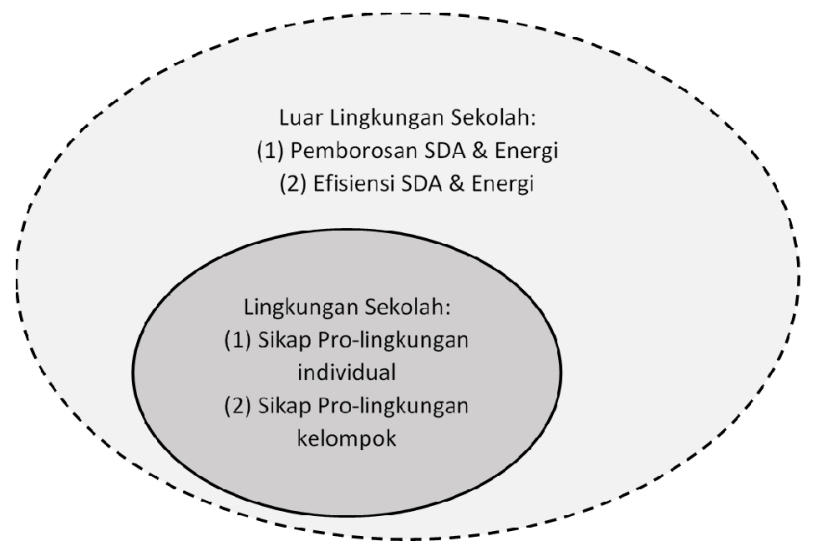

Gambar 2. Diagram Perilaku Ramah Lingkungan Adiwiyata (Sumber: Hasil analisis, 2019)

Perilaku ramah lingkungan siswa di luar sekolah di dalam penelitian lain juga dipandang sebagai sebuah kendala. Faktor eksternal seperti sosial dan ekonomi menjadi faktor utama yang menentukan kualitas perilaku siswa di luar sekolah (Rahmawati \& Suwanda, 2015). Sejalan dengan hal tersebut, Kollmuss dan Agyeman (2002) juga telah mengemukakan bahwa perilaku ramah lingkungan dalam perkembangannya akan dipengaruhi oleh berbagai faktor internal maupun eksternal dengan kompleksitas yang bermacam-macam pada masing-masing individu. Oleh karena itu, pembentukan perilaku ramah lingkungan pada siswa ini tidak bisa hanya dibebankan pada lingkungan sekolah.

\subsection{Hubungan Antara Nilai-nilai dan Perilaku Ramah Lingkungan di Sekolah Dasar Adiwiyata}

Setelah dilakukan analisis faktor pada kedua kriteria, langkah selanjutnya adalah melihat hubungan di antara kedua kriteria tersebut. Melalui analisis korelasi, masingmasing dimensi yang terdapat pada kriteria NEP-A maupun GEB-A dihubungkan dalam bentuk matriks dengan tujuan menemukan korelasi yang paling signifikan di antara dimensi-dimensi $N E P-A$ dan $G E B-A$. Dimensi yang didapat dari kriteria $N E P-A$ berperan sebagai faktor independen yang dapat mempengaruhi dimensi pada kriteria $G E B-A$ sebagai faktor dependen (Tabel 9).

Secara umum, dapat dikatakan bahwa "Sikap Pro-Lingkungan (Individual)" berturut-turut dipengaruhi signifikan oleh pemahaman siswa tentang "Edukasi Lingkungan", "Intervensi Konservatif", "Wawasan Lingkungan", dan "Eksploitasi Alam". Artinya, semakin tinggi pemahaman siswa tentang dimensi-dimensi tersebut, maka siswa 
akan cenderung semakin ramah lingkungan secara individu. Dimensi "Intervensi Destruktif" dapat dikatakan tidak menjadikan siswa bersikap ramah lingkungan karena dimensi ini berwujud paradigma yang menjadikan siswa tidak melakukan tindakan apa pun karena kekhawatiran akan kerusakan lingkungan, sehingga sikap ramah lingkungan tidak dapat terwujud. Sementara dimensi "Lingkungan Berkelanjutan" yang mewakili berbagai pemahaman tentang teknologi ramah lingkungan belum sepenuhnya dikuasai anak seusia Sekolah Dasar.

Selanjutnya, "Sikap Pro-Lingkungan (Kelompok)" berturut-turut dipengaruhi signifikan oleh pemahaman siswa tentang "Edukasi Lingkungan", "Intervensi Konservatif", "Lingkungan Berkelanjutan", dan "Eksploitasi Alam". Seperti pada "Sikap Pro-Lingkungan (Individual)", dimensi “Intervensi Destruktif” juga dapat dikatakan tidak menjadikan siswa bersikap ramah lingkungan secara berkelompok. Selain itu, dimensi "Wawasan Lingkungan" yang kualitasnya relatif pada setiap individu dalam hal ini juga tidak mampu memantik sikap ramah lingkungan secara berkelompok.

Hubungan antar-dimensi lainnya adalah sikap "Pemborosan SDA \& Energi” yang berturut-turut dipengaruhi signifikan oleh "Eksploitasi Alam" dan "Intervensi Destruktif". Pemborosan SDA dan energi dapat terjadi jika alam dieksploitasi secara terus-menerus. Siswa tidak boleh salah memahami bagaimana cara memanfaatkan sumber daya alam yang tersedia untuk keberlangsungan hidupnya. Kondisi ini berkaitan erat dengan pola pikir intervensi yang merusak lingkungan.

Selanjutnya, "Efisiensi SDA \& Energi" dipengaruhi oleh "Edukasi Lingkungan" dan "Wawasan Lingkungan". Proses edukasi lingkungan yang baik di sekolah akan memberikan wawasan lingkungan yang baik pula pada diri siswa. Edukasi lingkungan di sekolah berperan sebagai wadah pengetahuan yang bersifat teoretis dan terbatas. Oleh karena itu, edukasi lingkungan juga harus dilakukan di luar sekolah secara praktis untuk memperkaya wawasan lingkungan. Pengayaan wawasan lingkungan di luar sekolah akan menjadikan siswa bersikap efisien dan konservatif terhadap sumber daya alam dan energi.

Tabel 9. Korelasi Antara $N E P-A$ dan $G E B-A$

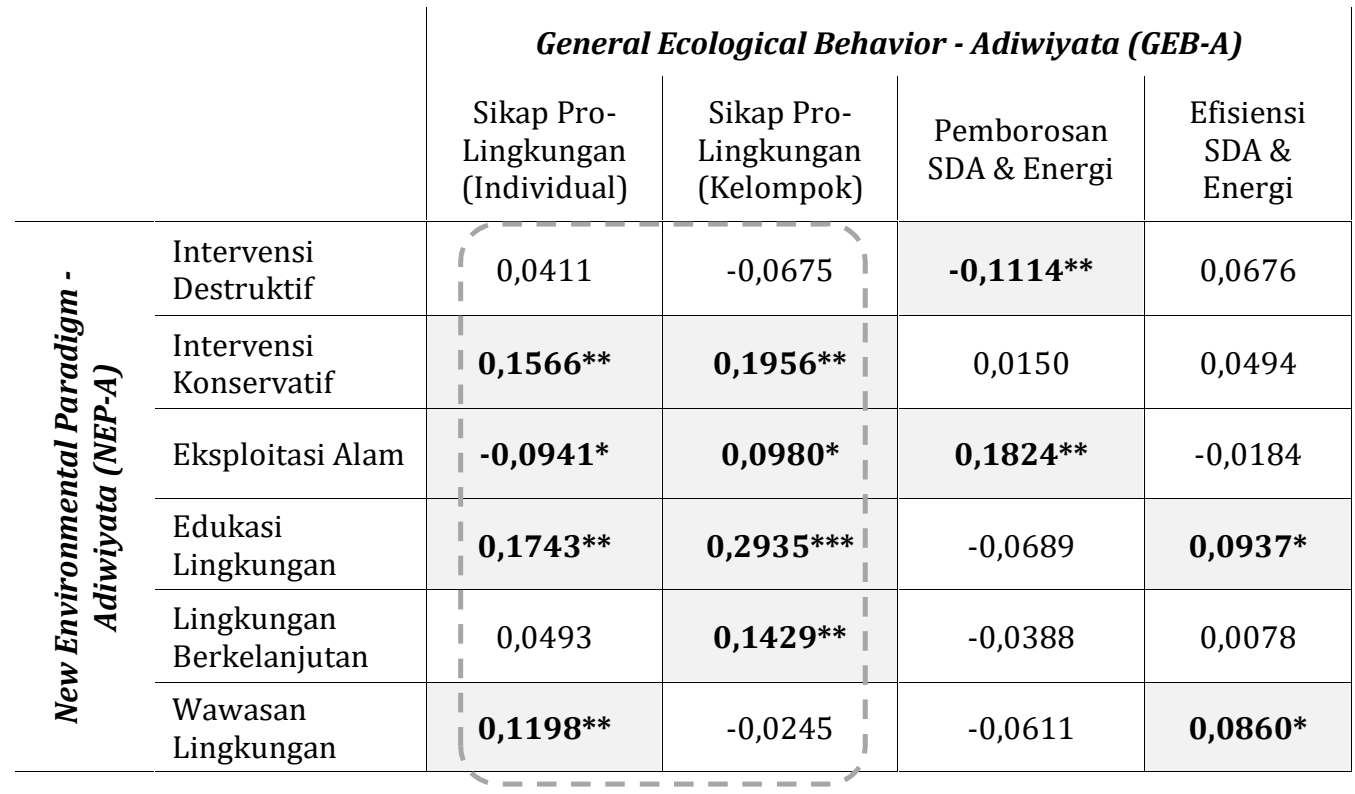

(Sumber: Hasil analisis, 2019)

Dimensi "Edukasi Lingkungan" pada kriteria $N E P-A$ berpengaruh paling besar dan signifikan hampir ke seluruh dimensi pada kriteria GEB-A. Hal ini sesuai dengan kondisi di lapangan karena "Edukasi Lingkungan" merupakan inti dari pendidikan lingkungan 
hidup yang terdapat di sekolah Adiwiyata. Aspek ini diinternalisasi secara efektif dan terus-menerus selama siswa bersekolah di Sekolah Dasar, sehingga pola pikir dan pemahaman terhadap nilai-nilai ramah lingkungan dapat tertanam dengan baik pada diri siswa masing-masing.

Penanaman perilaku ramah lingkungan pada siswa di sekolah yang paling efektif dapat dilakukan dengan memberikan pengaruh positif melalui pendekatan persuasif (dimensi "Sikap Pro-lingkungan Kelompok" mendapatkan skor paling tinggi pada tabel korelasi). Misalnya, mengajak para siswa membersihkan sampah di sekolah, menugasi siswa dengan membawa dan menanam tanaman di sekolah, atau bahkan mengajak para siswa berkontribusi untuk mengelola sampah di sekolah.

Matriks korelasi pada Tabel 9 memiliki pola umum yang dapat diinterpretasikan lebih dalam. Apabila kita lihat sisi faktor dependen ( $G E B-A)$, dimensi-dimensi yang banyak mendapatkan pengaruh dari NEP-A adalah dimensi yang memiliki lingkup aktivasi di lingkungan sekolah atau dimensi "Sikap Pro-Lingkungan (Individu)" dan "Sikap ProLingkungan (Kelompok)" (lihat Gambar 2). Artinya, lingkungan sekolah dengan segala kompleksitasnya - memiliki fungsi aktivasi perilaku pro-lingkungan dan merupakan wadah yang paling cocok untuk kegiatan edukasi lingkungan. Melalui kualitas lingkungan fisik, peraturan dan kurikulum, serta interaksi sosial yang terjadi secara alami, sekolah menjadi miniatur lingkungan hidup yang ideal dalam membentuk individu ramah lingkungan. Namun, pengembangan nilai-nilai dan perilaku ramah lingkungan siswa tidak bisa hanya dibebankan kepada lingkungan sekolah saja. Diperlukan kualitas lingkungan luar sekolah yang dapat memberikan pengaruh dan visi yang sama dengan lingkungan sekolah. Dengan kata lain, tujuan konsep sekolah Adiwiyata akan tercapai apabila didukung oleh lingkungan siswa di luar sekolah.

Terbatasnya durasi edukasi lingkungan yang terdapat di lingkungan sekolah berpotensi mengurangi intensitas internalisasi pengetahuan ramah lingkungan pada siswa. Akibatnya edukasi lingkungan hanya berada pada tahap memberikan pengetahuan dan kesadaran secara parsial (Hungerford \& Volk, 1990). Hal ini membuat siswa sebagai target edukasi memiliki perspektif norma lingkungan yang berbeda antara di dalam sekolah dan di luar sekolah. Siswa akan patuh dan berperilaku ramah lingkungan di dalam sekolah, tetapi di luar sekolah nilai-nilai tersebut mungkin diabaikan karena norma lingkungannya tidak sama lagi. Secara keseluruhan, dapat dikatakan bahwa pola pikir pengelolaan lingkungan "aktif" maupun "pasif" sebagai fondasi ekologis hanya dapat terwujud apabila berada di dalam lingkungan sekolah. Hal ini dapat dipengaruhi oleh kekuatan fungsi kontrol yang terdapat di sekolah. Sementara itu, di luar lingkungan sekolah yang minim fungsi kontrol, pola pikir ramah lingkungan dapat dikatakan sulit untuk diwujudkan.

\section{Simpulan}

Berdasarkan hasil penelitian, terdapat enam dimensi pola pikir ramah lingkungan (NEP-A) dan empat dimensi (GEB-A) yang dapat dikembangkan melalui sekolah Adiwiyata. Pada kriteria pola pikir ramah lingkungan (NEP-A), terdapat dimensi "Intervensi Destruktif", "Intervensi Konservatif", "Eksploitasi Alam", "Edukasi Lingkungan", "Lingkungan Berkelanjutan”, dan "Wawasan Lingkungan”. Keenam dimensi pola pikir tersebut terbagi menjadi dua kelompok besar, yaitu pola pikir pengelolaan lingkungan "aktif" dan "pasif".

Pada kriteria perilaku ramah lingkungan $(G E B-A)$, terdapat dimensi "Sikap ProLingkungan (Individual)", "Sikap Pro-Lingkungan (Kelompok)”, "Pemborosan SDA \& Energi", serta "Efisiensi SDA \& Energi". Keempat dimensi tersebut memiliki dua ruang lingkup aktivasi utama, yaitu di dalam lingkungan sekolah dan di luar lingkungan sekolah. 
Hasil analisis korelasi yang signifikan menunjukkan bahwa pola pikir pengelolaan lingkungan "aktif" maupun "pasif" sebagai fondasi ekologis hanya dapat terwujud apabila berada di dalam lingkungan sekolah. Sementara di luar sekolah nilai-nilai dan perilaku ramah lingkungan sulit diwujudkan. Hal ini menunjukkan bahwa nilai pola pikir dan perilaku ramah lingkungan siswa yang ditanamkan oleh sekolah Adiwiyata masih perlu didukung oleh pengawasan pihak lainnya di luar sekolah. Penanaman nilai-nilai dasar di sekolah saja tidak cukup untuk menjadikan pola pikir dan perilaku ramah lingkungan siswa menjadi ajek dan terbawa secara alami di lingkungannya sehari-hari. Artinya, pelaksanaan edukasi lingkungan tidak bisa dilakukan secara parsial, tetapi harus menyeluruh baik dari aspek lingkungan fisik maupun sosial, baik di dalam sekolah maupun di luar sekolah.

Dimensi-dimensi di atas adalah dimensi NEP dan GEB yang sudah disesuaikan (diverifikasi) ke dalam konteks Indonesia. Diharapkan temuan ini memiliki kontribusi yang signifikan untuk penelitian terkait pengembangan nilai-nilai pola pikir dan perilaku ramah lingkungan di Indonesia.

\section{Rekomendasi}

Situasi dan kondisi sekolah yang dinilai pada studi ini hanya mewakili sekolah dasar di wilayah Bandung. Mengingat keragaman tradisi, budaya, dan regulasi yang berbedabeda di setiap wilayah, penelitian sejenis juga dapat dilakukan di wilayah lainnya. Hal ini dapat memperkaya temuan penelitian dan menyempurnakan pengembangan edukasi lingkungan di Indonesia. Selain itu, replikasi penelitian ini juga akan memverifikasi temuan-temuan dimensi $N E P$ dan $G E B$ versi Indonesia. Temuan dimensi-dimensi yang konsisten/setara akan memperkuat teori yang diajukan di dalam studi ini.

\section{Daftar Pustaka}

Chawla, L. (1999). Life Paths Into Effective Environmental Action. The Journal of Environmental Education, 31(1), 15-26. doi:10.1080/00958969909598628

Corraliza, J. A., Collado, S., \& Bethelmy, L. (2013). Spanish Version of the New Ecological Paradigm Scale for Children. Spanish Journal of Psychology, 16(27), 1-8. doi:10.1017/sjp.2013.46

De, A. K., \& De, A. K. (2004). Environmental Education. New Delhi: New Age International Ltd.

Dunlap, R. E., \& Van-Liere, K. D. (1978). The "New Environemntal Paradigm". Journal of Environmental Education, 9(4), 10-19.

Dunlap, R. E., Van-Liere, K. D., Mertig, A. G., \& Jones, R. E. (2000). Measuring endorsement of the New Ecological Paradigm: a revised NEP scale. Journal of Social Issues, 56(3), 425-442.

Evans, G. W., Brauchle, G. H., \& Shapiro, E. (2007). Young Children's Environemntal Attitudes and Behaviors. Environment and Behavior, 39(5), 635-658.

Ghaziani, R. (2008). Children's voices: raised issues for school design. CoDesign, 4(4), 225236. doi:10.1080/15710880802536403

Gusti, A., Isyandi, B., Bahri, S., \& Afandi, D. (2015). HUBUNGAN PENGETAHUAN, SIKAP DAN INTENSI PERILAKU PENGELOLAAN SAMPAH BERKELANJUTAN PADA SISWA SEKOLAH DASAR DI KOTA PADANG. Dinamika Lingkungan Indonesia, 2(2), 100107.

Hungerford, H. R., \& Volk, T. L. (1990). Changing Learner Behavior Through Environmental Education. The Journal of Environmental Education, 21(3), 8-21. doi:doi:10.1080/00958964.1990.10753743 
Johnson, R. A., \& Wichern, D. W. (1998). Applied Multivariate Statistical Analysis. New Jersey: Prentice-Hall International Inc.

Kaiser, F. G. (1998). A General Measure of Ecological Behavior. Journal of Applied Social Psychology, 28(5), 395-442.

Kaiser, H. F. (1960). THE APLICATION OF ELECTRONIC COMPUTERS TO FACTOR ANALYSIS. Educational and Psychological Measurement, XX(1), 141-151. doi:10.1177/001316446002000116

Kementerian Lingkungan Hidup. (2012). Buku Panduan Pelaksanaan Program Adiwiyata. Jakarta: Kementerian Lingkungan Hidup.

Kementerian Lingkungan Hidup. (2013). Permen LH No. 05 Tahun 2013 Tentang Pedoman Pelaksanaan Program Adiwiyata. Jakarta: Kementerian Lingkungan Hidup.

Kollmus, A., \& Agyeman, J. (2002). Mind the Gap: Why do people act environmentally and what are the barriers to pro-environmental behavior? Environmental Education Research, 8(3), 239-260. doi:10.1080/13504620220145401

Kurisu, K. (2015). Pro-evironmental Behaviors. Tokyo: Springer.

Kusuma, Y., Kusuma, H. E., Tampubolon, A. C., \& Aryanti, T. (2019). Pengaruh Kualitas Lingkungan dan Motivasi pada Kinerja Akademik Siswa SMA. RUAS (Review of Urbanism and Architectural Studies), 16(2), 28-41.

Manoli, C. C., Johnson, B., \& Dunlap, R. E. (2010). Assessing Children's Environmental Worldviews: Modifying and Validating the New Ecological Paradigm Scale for Use With Children. The Journal of Environmental Education, 38(4), 3-13. doi:10.3200/JOEE.38.4.3-13

Manurung, Y. L. (2011). PROGRAM ADIWIYATA DALAM PENGELOLAAN LINGKUNGAN SEKOLAH (studi kasus SDN Panggung 04 Kecamatan Jepara Kabupaten Jepara Provinsi Jawa Tengah). Universitas Diponegoro.

Rahmawati, I., \& Suwanda, I. M. (2015). Upaya Pembentukan Perilaku Peduli Lingkungan Siswa Melalui Sekolah Adiwiyata di SMP Negeri 28 Surabaya. Kajian Moral dan Kewarganegaraan, 1(3), 71-88.

Saifuddin, A. (2001). Metode Penelitian. Yogyakarta: Pustaka Belajar.

Saragih, A. A. (2012). Pengaruh Program Adiwiyata Terhadap Kognitif Afektif Dan Psikomotorik Lingkungan Hidup Siswa Sekolah Dasar Di Kota Medan (Studi Kasus di SD Swasta Pertiwi dan SD Negeri 060843 Kec. Medan Barat). Universitas Sumatera Utara.

Sujiono, Y. N. (2009). Konsep Dasar Pendidikan Anak Usia Dini. Jakarta: PT. Indeks.

Tucker, R., \& Izadpanahi, P. (2017). Live green, think green: Sustainable school architecture and children's environmental attitudes and behaviors. Journal of Environmental Psychology, 51(2017), 209-216. doi:10.1016/j.jenvp.2017.04.003

UNESCO. (2018, March 3). Promoting Adiwiyata Green Schools and Empowering Low Income Communities for Sustainable Future of Indonesia. Diambil kembali dari UNESCO: http://www.unesco.org/new/en/jakarta/education/education-forsustainable-development/promoting-adiwiyata-green-schools/

White, R., \& Stoecklin, V. L. (2008). Nurturting Children's Biophilia: Developmentally Appropriate Environmenta Education for Young Children. Dipetik September 27, 2018, dari LIve-Learn: https://www.livelearn.org/resources/teachers/A_Sense_of_Place_Conference/Biophilia.pdf

Widiyaningrum, P., Lisdiana, L., \& Purwantoyo, E. (2015). Evaluasi Partisipasi Siswa Dalam Pengelolaan Sampah Untuk Mendukung Program Sekolah Adiwiyata. Indonesian Journal of Conservation, 4(1), 74-82. 